\title{
Assurance of heating systems maintenance reliability through the creation of a risk management system of the heat-supplying organizations
}

\author{
Natalia Verstina ${ }^{1 *}$, Anna Badalova ${ }^{2}$ and Evgeny Evseev ${ }^{3}$ \\ ${ }^{1}$ Moscow State University of Civil Engineering, Yaroslavskoe shosse, 26, Moscow, 129337, Russia \\ ${ }^{2}$ Moscow State Technological University STANKIN, 127055, 3a, Vadkovsky Lane, Moscow, Russia \\ ${ }^{3}$ Moscow Institute of Physics and Technology, 141700, 9, Institutskiy per., Dolgoprudny, Moscow \\ Region, Russian Federation
}

\begin{abstract}
The matters of the organization of risk management of the heatsupplying organizations (HSO), focused on the increase in the reliability of the heating systems maintenance are considered in the article. The characteristic of the current maintenance conditions of HSO in the countries of the former Soviet Union, which distinction is the existence of some state plans for the change of the heat-supplying industry development financing in the Russian Federation and Uzbekistan, similar in the target orientation. The new methodological-and-methodical approach to the determination of the interrelation between the heating systems maintenance reliability and the risks of HSO with their differentiation according to the significance values, complemented with the classification of risks on the basis of the equilibrium-and-balanced approach and the formation of the matrix for risk analysis is offered as the research result. Due to the purpose of the creation of risk management system in HSO the current state of the information support of their activity, which is recognized insufficient, is studied. The results of the analysis of the interrelation between the reasons of failures during the delivery of heat to consumers because of risks, having constructive, technologic and labour character, and stages of the heating systems lifecycle are presented. Three models of the assessment of the level of engineering structures reliability, depending on the assessment of situation in HSO are offered to the discussion. The risk management system in HSO is considered as an important condition of the reliability assurance, the substantial characteristic of its main components is given.
\end{abstract}

\section{Introduction}

Nowadays some consequences of laying of heating systems of "the socialist period" of our history, which characterized with low quality of design, construction and also the low level

\footnotetext{
* Corresponding author: verstina@mail.ru
} 
of the organization of the engineering structures maintenance emerge in the countries of the former Soviet Union, including the Russian Federation and Uzbekistan. That led to the decrease in the heating systems reliability eventually and raised the issues of reorganization of management for overcoming the old approaches to the organization of maintenance as well as for the development of modern methods of management. Both motivation to the TSOs transformations and the state policy in the heat supplying industry, which is being carried out by the government act as important factors of realization of such a transition. The laws, governing the relations of the participants of heat supply make up the basis for the heat supplying activity in both countries. At the same time new mechanisms of the industry financing, which provide qualitatively different opportunities for the improvement of management in TSO, have entered the processes of reorganization of the industry in both countries recently.

The industry of heat supply in the Russian Federation is now in anticipation of great changes which received the legal framework after adoption of the law of the Russian Federation "On Heat Supply" in 2017. According to the law provisions the Russian heatsupplying organizations have to carry out considerable transformations in management of their productive activity, which core is the issue of assurance of heat supply reliability. The matter of the heating systems wear, which predetermines the low reliability of heat supply both at the level of separate HSO, and in the scales of all the Russian Federation is discussed at the level of the state, in the scientific environment and at the expert sites [1]. The programme documents in the development of energy in our country define the directions of the development of technical and technological solutions of energy supply facilities, but it is still not clear how to overcome the "log" between the progressive constructive decisions for the heating systems of the future and their low current technological level. And respectively, it is not clear how to pass from low the reliability of the heating systems under maintenance to the reliability at the level of the best international standards. There are some data, which allow to estimate the scale of the problem of the reliability assurance which became chronic for the domestic practice in the last decades. While the total extent of the heating systems in the regions of the Russian Federation in two-pipe calculation is about 185 thousand $\mathrm{km}$, according to the expert evaluations at least 48 thousand $\mathrm{km}$ of them require replacement; that makes more than $25 \%$ of the engineering structures.

The same problems are also present in many partner countries of the Russian Federation (in the former Soviet Union territory) including in Uzbekistan. The share of systems of the centralized heat supply is considerable in the country, and according to the experts, the technological potential of energy saving of those systems is estimated at 50\% now [2]. The reasons for low reliability, similar to the Russian Federation, are named; they are the following: the considerable part of structures was created in 1950...1980, and more than a half of the heating systems under maintenance were laid in 1993...2012 [3]. In this regard the approval of "Development programme of the heat supply system for 2018-2022" in which the transition to power saving and resource-saving technologies and equipment is provided became an important movement. Some financial instruments of the realization of the planned prospects were also chosen [4]. The similarity of the situation regarding the heating systems reliability of our countries and the chosen directions of the solution of the matters existing, testify that, the measures for their implementation can be mutually interesting too.

The relevance of ensuring reliability of the heating systems in our countries led to the numerous discussions, developing both in technical and in managerial aspects. Very reasoned offers, including ours, were expressed about the need of improvement of technical means and technologies of diagnostics of the heating systems condition, about the development of information systems with data on the engineering systems maintenance, on 
carrying out large-scale reconstruction of heating systems, etc. Recognizing the importance of these discussions, the authors at the same time consider it important to concentrate the attention of researchers and practicians on the heat-supplying organizations (HSO) as the main subject of heat supply in the territory of the dislocation. The experience proves, that any strategic decisions, made in the heat supplying industry, including those on the increase in the heating systems reliability, have to be without fail be supported by the corresponding managerial tools in HSO, which become the guarantors of stability of the carried-out changes.

The orientation of HSO to the minimization of risks, connected with the maintenance of the worn-out heating systems and the lack of adequate data on the condition of all the engineering structures of the heating systems of the organization, becomes the key control point for the solution of issues of the heating systems reliability. The reliability is the condition in the HSO activity, which is in the inverse proportion to risks; i.e. the lower the risks of failure of the heating systems and the consequences connected with it for the HSO, the higher the reliability of the heating systems, operated by it. Possible consequences of the exception of risks of the range of matters of reliability management are rather different: from unforeseen costs in connection with the arisen emergency at the heating systems to significant losses in the scales of the whole HSO, connected with incorrect decisions on the organization of financing of actions for updating of heating systems. In this regard the authors made an attempt to study the main aspects of the creation of the risk management system of HSO, taking into account the need of assurance of the heating systems maintenance reliability.

\section{Materials and Methods}

Assurance of the heating systems maintenance reliability is a system and complex scientific and applied issue owing to the multi-aspect of the category of reliability. This provision predetermines the opportunity and expediency of reliability assurance on different directions with the use of various tools: managerial, organizational-and-technical, technological, mathematical, etc. One of such directions is the risk management, and tools include the methods and procedures of risk assessment and risk management, carried out within the creation and the use of risk management system of HSO.

The development of methodological principles of assurance of the heating systems maintenance reliability on the basis of the creation of risk management system of HSO predetermines the solution of four fundamental issues:

1) refining of the concept of the engineering structures maintenance reliability HSO heating systems;

2) identification of the interrelation between reliability and risks;

3) development of the approach to classification of risks;

4) carrying out the classification of risks within the risk management system of HSO.

The features of the category of "reliability" are its universality and debatability (at the same time). The universality appears when the reliability is integrated to functioning and development of practically any process and an facility, including the organization (including HSO), heating systems maintenance, etc. At the same time the debatability appears in the use of various indicators and parameters of the assessment of reliability level, as well as the instruments of the reliability assurance in relation to separate facilities and processes.

Thus, there is the need of refining of the concept of reliability in relation to the heating systems maintenance and as well as the definition of assessment/measurement indicators for the reliability. 
We use the term reliability of the heating systems maintenance for their capability and possibility of failures in HSO.

Therefore, the indicators of quantitative assessment of the heating systems maintenance reliability are time/terms $(\mathrm{T})$, volume $(\mathrm{V})$ and quality $(\mathrm{Q})$ of the provided services. The level of reliability $\left(\mathrm{R}_{1}\right)$ which is the function of the specified three factors, acts as the indicator of the quantitative assessment of reliability, i.e.

$$
R_{l}=f(T, V, Q)
$$

We can address the interrelation of reliability and risks. The conducted research allows to point out two aspects of interrelation of reliability of the heating systems maintenance and risks:

1) cause-and-effect aspect;

2) estimated-and-parametrical aspect.

The cause-and-effect interrelation appears when the risk management allows to raise and provide the required level of reliability of the heating systems maintenance, namely to provide the proper services of heat supply of the required volume and quality in the required terms.

The estimated-and-parametrical aspect of interrelation of reliability and risks is connected with:

- the inversely proportional dependence of reliability and risks, noted earlier in Introduction, i.e. the higher risk level, the lower reliability level and vice versa;

- the use of identical indicators/parameters for the quantitative assessment, namely: it is offered to use time/term (T), volume (V) and quality (Q) of the provided services for the assessment of reliability; the deviation from the required (planned) values of these indicators allows to estimate risk.

It is offered to use the three-level scale of measurement:

- low level of reliability and high, near-critical risk level;

-average level of reliability and average level of risk;

- high level of reliability and low level of risk.

The solution of the issue of classification of risks is the most significant in the theoretical-and-applied aspect. The classification of risks allows to concretize the subject of managerial influence and to increase the effectiveness and effective management of risks, and, therefore, to provide the reliability of the heating systems maintenance.

The research, carried out by the authors allow to recommend the equilibrium-andbalanced approach as the priority approach to the classification of risks. The equilibrium appears in that the offered approach assumes to carry out the classification of risks at 2 levels:

1) the HSO level in general, i.e. the classification of risks of functioning of the organization, summary classification;

2) the level of the heating systems under maintenance, i.e. the classification of risks of the heating systems under maintenance, particular classification.

The specified two types of classification are supplementing and counterbalancing for each other in case of for the solution of the scientific-and-applied issues of the assurance of the heating systems maintenance reliability on the basis of the creation of the risk management system of HSO.

It is necessary to specify that during classification and further assessment, monitoring and managerial influence on risks such types of resources as production, information, logistic, financial, labour and information resources are considered.

So, when developing the summary classification, the typology of risks is carried out and their types are defined by the means of the projection of 6 types of resources and 7 aspects of the HSO environment to the 4 processes of providing with services (the processes of providing consumers with heat energy). 
When developing the particular classification, the types of risks are defined by the means of the projection 3 components of processes of heat supply on 3 parameters of services of delivery of heat.

The research, carried out by the authors allow to recommend to use the structural elements of the heating systems, main and auxiliary technologies and the organization of the personnel work (i.e. the functions and qualification of personnel) as the components of the processes of heat supply.

When developing the typology of risks of functioning of HSO the authors offered and considered the balanced approach to the classification of risks in detail. The name of the specified tool is being specified, and the authors use a concept of summary classification and "matrix of seventeen". "Seventeen" means the quantity of groups of the risks, formed when with the use of the considered approach to the classification of risks.

The second level of classification of risks, i.e. risks of the heating systems maintenance, is connected with the particular classification, carried out with the use of so-called "matrix of seven". Following the chosen logic, the classification means the formation of nine particular groups of risks. The graphic interpretation of the offered tool is presented in the form of a matrix (Table 1).

Table 1. Classification of risks of the heating systems maintenance (particular classification of risks "MATRIX of SEVEN")

\begin{tabular}{|c|c|c|c|c|}
\hline \multirow{2}{*}{$\begin{array}{l}\text { Components of the heat } \\
\text { supply processes }\end{array}$} & \multicolumn{3}{|c|}{ Parameters of the services of the heat delivery } & \multirow[b]{2}{*}{ Groups of risks } \\
\hline & Time / Terms & Volume & Quantity & \\
\hline $\begin{array}{l}\text { Structural elements of the } \\
\text { heating systems }\end{array}$ & $\mathrm{r}_{11}$ & $r_{12}$ & $\mathrm{r}_{13}$ & $\begin{array}{l}\text { Constructive } \\
\text { risks }\left(\mathrm{r}_{1}\right)\end{array}$ \\
\hline $\begin{array}{l}\text { Technologies (main and } \\
\text { auxiliary) }\end{array}$ & $\mathrm{r}_{21}$ & $r_{22}$ & $r_{23}$ & $\begin{array}{l}\text { Technological } \\
\text { risks }\left(\mathrm{r}_{2}\right)\end{array}$ \\
\hline $\begin{array}{l}\text { Organization of the } \\
\text { personnel work (functions } \\
\text { and qualification of the } \\
\text { personnel) }\end{array}$ & $\mathrm{r}_{31}$ & $r_{32}$ & $r_{33}$ & $\begin{array}{l}\text { Labour risks } \\
\left(\mathrm{r}_{3}\right)\end{array}$ \\
\hline Others & $\mathrm{r}_{41}$ & $\mathrm{r}_{42}$ & $\mathrm{r}_{43}$ & Other risks $\left(r_{4}\right)$ \\
\hline Groups of risks & $\begin{array}{l}\text { Time-frame } \\
\text { risks (risks of } \\
\text { term) }\left(\mathrm{r}_{5}\right)\end{array}$ & $\begin{array}{c}\text { Volume } \\
\text { risks (risks } \\
\text { of volume) } \\
\left(\mathrm{r}_{6}\right)\end{array}$ & $\begin{array}{l}\text { Qualitative risks } \\
\text { (risks of quality) } \\
\qquad\left(\mathrm{r}_{7}\right)\end{array}$ & \\
\hline
\end{tabular}

It is necessary to mention, that these two matrixes "matrix of seventeen" and "matrix of seven" are not dogmatic, and their application as the tool for risk identification in a specific HSO and taking into account the structure of its heating systems economy, supposes flexible control of matrixes.

\section{Results}

We consider basic elements of the approach to the implementation of quality and quantitative assessment of the reliability, developed by the authors, which is to be used during the creation of the risk management system of HSO. It was accepted as the starting moment of the research that analysing information, available to management in modern 
Russian HSO, we should undertake the assessment of the information support of the processes of the heating systems in their current condition in the aspect of the use of particular classification of risks of "matrix of seven".

Previously we can formulate some general methodical provisions:

- the core of the definition of the quantitative indicators of the reliability, used in the risk management system always has to include the analysis of design, structural, operational features of the engineering structures for three stages of the project life cycle, affecting the reliability of their maintenance, connected with the emergence and development of damages, defects on the pipelines and other structures of the heating systems;

- on the basis of the analysis of features of the heating systems and accounting of the components of the heat supply processes (Table 1) it is necessary to define the subjects of the priority monitoring from the positions of reliability assurance and risks minimization, to reveal the quantitative characteristics of the change of reliability in time projection in dependence on the features of heating systems economy;

- having information on the subjects of priority monitoring from the positions of reliability assurance and risk minimization, to define the available control methods of technical condition of the heating systems as well as the plans of their monitoring, taking into account the requirements of risks management system.

Earlier the authors formulated the evidence-based offers, which underwent the experimental testing, focused on HSO, motivated on the assurance of the reliability of the heating systems under maintenance and system work on the organization of information support of this activity [5]. The processes of the reorganization of traditional practice of work of HSO, which developed without any scientifically based approaches to the organization of information on the reliability of the heating systems, occurs difficult, in some cases it takes the forms of incidental decisions. At the same time, the risk management in HSO has to integrate the whole complex of versatile information, which will allow to pass to the system risk management.

We can consider it in more detail, taking into account the general provisions, given above, in the aspect of orientation to the creation of the risk management system of HSO. The analysis of the features of the heating systems, affecting the reliability of their maintenance and connected with the emergence and development of damages, defects on the pipelines and other structures, which was carried out on the basis of this long-term studying the work of engineering structures, allowed to reveal the existence of the reasons of their emergence during all the stages of the life cycle: during design, construction and maintenance. At the same time the opportunity to affect immediately the causes of risks in the use of the heating systems which arose during the first two stages is absent. The third stage can be regulated and adjusted by the HSO management, however, the calculations, made by the authors, correlated to the expert estimates, proved that the distribution of shares of the risks emergence because of the negative events on the given three stages, is estimated as 25:65:10. It is important to mean this proportion during the creation of the information support of the risk management system of $\mathrm{HSO}$ and its use for the identification of risks, according to the offered classification.

The analysis of the reasons of the decrease in the reliability of the work of the HSO heating systems during the three stages of the life cycle allowed to concretize the subjects of monitoring, connected with the processes of the risks accumulation. During the design stage of the heating systems the most problematic issues have always been the mistakes of designers, caused by the use of the initial information on the external environment of insufficient quality, because of the lack of the survey works of the required volume (in particular during the turn of sites of heating systems), incorrectness in the strength calculations of structures of the pipelines, because of which the risk of the emergence of 
breach during the maintenance is already predetermined, as well as the lack of the required information on the operational properties of the materials, used for the design decisions. The possible source of mistakes is also the use of standard structures of the heating systems by the designers without the appropriate check of their applicability to the specific conditions of maintenance. The proper attention to the projection is not always paid to the parameters of the drainage systems, which reliability during maintenance is less required. There is one more unresolved issue of the assurance of the reliability of joint work of all the structural elements of the engineering structure: in case of a standard serviceable life of the heating systems it makes up 25 years, during the design stage the heat-insulating materials with a period of validity no more than 10 years can be chosen. There are also some defects in the design, peculiar to separate types of laying of the heating systems. The list of the main sources of emergence of risks during the maintenance of the HSO heating systems during the design stage, analysed by the authors from the reliability positions is presented in the Table 2 .

Table 2. Specifics of the heating systems design, affecting the reliability of their maintenance because of the "creation" of constructive risks

\begin{tabular}{|c|c|c|c|}
\hline № & $\begin{array}{c}\text { Reason of the decrease in the } \\
\text { reliability and subjects of the } \\
\text { priority monitoring }\end{array}$ & $\begin{array}{c}\text { Negative consequences during } \\
\text { the heating systems } \\
\text { maintenance }\end{array}$ & Defects, damages \\
\hline 1 & $\begin{array}{c}\text { Incorrect strength calculation of } \\
\text { the engineering construction } \\
\text { designs }\end{array}$ & $\begin{array}{c}\text { Compensation violation, } \\
\text { emergence of the intense } \\
\text { deformable state, which } \\
\text { increases the corrosion rate 10 } \\
\text { times in case of simultaneous } \\
\text { humidification }\end{array}$ & External corrosion \\
\hline 2 & $\begin{array}{c}\text { Use of insufficient information } \\
\text { on the research for the choice of } \\
\text { design decisions } \\
\text { (reconstruction, lining) }\end{array}$ & $\begin{array}{c}\text { Emergence of unforesen } \\
\text { humidification of the structures } \\
\text { of the heating systems ubder } \\
\text { maintenance }\end{array}$ & External corrosion \\
\hline 3 & $\begin{array}{c}\text { The choice of constructive } \\
\text { materials for the heating } \\
\text { systems with various endurance }\end{array}$ & $\begin{array}{c}\text { Decrease and loss of } \\
\text { operational properties of the } \\
\text { constructive materials }\end{array}$ & External corrosion \\
\hline 4 & $\begin{array}{c}\text { Insufficient study of the } \\
\text { constructive decisions for the } \\
\text { the separate elements (drainage, } \\
\text { waterproofing) }\end{array}$ & $\begin{array}{c}\text { Emergence of unforesen } \\
\text { humidification of the structures } \\
\text { of the heating systems ubder } \\
\text { maintenance }\end{array}$ & External corrosion \\
\hline
\end{tabular}

As for the assessment of the current information support of the risk management system of $\mathrm{HSO}$, the requirement on the obligatory quality control of the project documentation for the new construction and reconstruction of heating systems economy of HSO, cardinally different from the modern practice, became the partial conclusion, made by the authors, according to the results of the analysis, and directed to the exception of the constructive risks of the decrease in the reliability, owing to design, which can increase the shortcomings of the reliability assurance during the two other stages of the life cycle.

The construction stage, as well as production of repairs of the heating systems remains the most problem point in terms of the reliability in the Russian HSO. While there is the relative simplicity of the technological processes of laying, the majority of the reasons of the low reliability of the engineering structures is localized at the construction stage. The main thing that should be excluded during construction, is the existence of any opportunities of humidification of the engineering structures during the maintenance. The carried-out analysis of the reasons proved, that the most essential of them is the group, leading eventually to the emergence of different types of corrosion damages on the external surface of the heating systems, owing to the contact of metal elements with water, which is 
in their surrounding medium [5]. Therefore, the operational quality control is important: the beforehand coated pipelines should be unloaded, stored and mounted keeping a wholeness of all the armour coats. For obtaining the information on soaking of the structure of the channelless heating systems, the system of the operating remote control, which violation during construction can lead to some technological risks, is provided in the industrial conditions. Low-quality materials and products of the structures of the heating systems, which can be also added to the defects of installation along with low qualification of workers, become the reasons of not corrosion damages of the engineering structures. [6]. The list of the main reasons for the decrease in the reliability of work of the HSO heating systems, arising during the construction stage, because of the "creation" of constructive and technological risks, analysed by authors, is presented in Table 3.

Table 3. Specifics of the heating systems design, affecting the reliability of their maintenance because of the "creation" of constructive and technological risks

\begin{tabular}{|c|c|c|c|}
\hline № & $\begin{array}{c}\text { Reason of the decrease in the } \\
\text { reliability and subjects of the } \\
\text { priority monitoring }\end{array}$ & $\begin{array}{c}\text { Negative consequences during the } \\
\text { heating systems maintenance }\end{array}$ & $\begin{array}{c}\text { Defects, } \\
\text { damages }\end{array}$ \\
\hline 1 & $\begin{array}{c}\text { Use of low-quality materials, } \\
\text { pipes and structures (weak } \\
\text { adhesion, density lower than } \\
\text { demanded) }\end{array}$ & $\begin{array}{c}\text { Possibility of penetration of moisture } \\
\text { through through the structure }\end{array}$ & $\begin{array}{c}\text { External } \\
\text { corrosion }\end{array}$ \\
\hline 2 & $\begin{array}{c}\text { Violation of conditions of } \\
\text { unloading and warehousing of } \\
\text { pipes in polyurethane foam } \\
\text { insulation }\end{array}$ & $\begin{array}{c}\text { Violation of the wholeness of the } \\
\text { heating system structure }\end{array}$ & $\begin{array}{c}\text { External } \\
\text { corrosion }\end{array}$ \\
\hline 3 & $\begin{array}{c}\text { Violation of technology of } \\
\text { installation }\end{array}$ & $\begin{array}{c}\text { Violation of a wholeness of the } \\
\text { heating system structure }\end{array}$ & $\begin{array}{c}\text { External } \\
\text { corrosion }\end{array}$ \\
\hline 4 & $\begin{array}{c}\text { Low-quality seal of joints of the } \\
\text { pipeline }\end{array}$ & $\begin{array}{c}\text { Penetration of moisture to metal } \\
\text { during the maintenance }\end{array}$ & $\begin{array}{c}\text { External } \\
\text { corrosion }\end{array}$ \\
\hline 5 & $\begin{array}{c}\text { Low-quality welding of pipes } \\
\text { metal }\end{array}$ & Rupture of joint welds & $\begin{array}{c}\text { Not-corrosion } \\
\text { defect }\end{array}$ \\
\hline 6 & $\begin{array}{c}\text { Low qualification of workers and } \\
\text { production culture }\end{array}$ & $\begin{array}{c}\text { Opportunity of emergence of defects } \\
\text { when performing any process }\end{array}$ & $\begin{array}{c}\text { All types of } \\
\text { defects }\end{array}$ \\
\hline
\end{tabular}

As for the assessment of the current information support of the risk management system of HSO during construction, it is possible to note the main problem, i.e. the lack of qualitative project documentation which has to be transferred to HSO in electronic form. The experience of foreign countries, is interesting to adopt, (particularly the European countries, Germany and Denmark are interesting in this regard), as it is useful for HSO, focused on the modern management and on ensuring reliability of engineering structures. Accepting of the heating systems for the maintenance, is carried out taking into account the conclusions of independent examination of the engineering company, which bears the further responsibility for the issued conclusions. It is apparent that this offer still can be a subject of discussions, however, otherwise the updating of the heating systems economy, can repeat the numerous mistakes, resulting in constructive and technological risks of the heating systems.

As for the maintenance stage the research by the authors proved that the matter of assurance of the heating systems work reliability in the Russian HSO, in the countries of the former Soviet Union and abroad differs a little [5, 6, 7]. In Russia the reliability is mainly defined by already available damages and defects during the heating systems work, while in foreign practice the reliability is much higher and HSO are focused on timely detection and elimination of the factors which can result in malfunctions of the heating systems elements eventually. 
The analysis of the organization of management in the Russian HSO proved, the main problem during the reliability assurance and the creation of fully functioning risk management system of HSO is the lack of information. The universal practice of HSO is the use of information of the "historically developed" formats, which suppliers are appointed at the discretion of the management. It is accompanied by the technological and personnel risks, peculiar to this stage of life cycle of the heating systems. Therefore, as it is important to provide a source of information of the risk management system of HSO the initial step, to adjust work of the trained personnel, which regularly make rounds of engineering structures and correctly fixes their results. The list of the main reasons for the decrease in the reliability of the HSO heating systems work during the maintenance stage, owing to the emergence of technological and labour risks, which is caused by the inadequate attention to the information support, is presented in the Table 4.

Table 4. Specifics of the heating systems design, affecting the reliability of their maintenance because of the appearence of the technological and labour risks

\begin{tabular}{|l|l|l|l|}
\hline № & $\begin{array}{l}\text { Reason of the decrease in the } \\
\text { reliability and subjects of priority } \\
\text { monitoring }\end{array}$ & $\begin{array}{c}\text { Negative consequences } \\
\text { during the maintenance }\end{array}$ & $\begin{array}{l}\text { Significance the risk } \\
\text { management system }\end{array}$ \\
\hline 1 & $\begin{array}{l}\text { Absence of egular rounds of the } \\
\text { heating systems }\end{array}$ & $\begin{array}{l}\text { Failure of data for the } \\
\text { reliability assessment }\end{array}$ & $\begin{array}{l}\text { System-wide, results } \\
\text { in incorrectness of the } \\
\text { estimates }\end{array}$ \\
\hline 2 & $\begin{array}{l}\text { Lack of all the data on the } \\
\text { maintenance (temperature, mode) } \\
\text { in the dispatching HSO }\end{array}$ & $\begin{array}{l}\text { Failure of data for the } \\
\text { reliability assessment }\end{array}$ & $\begin{array}{l}\text { System-wide, leads to } \\
\text { not acceptance of the } \\
\text { required measures }\end{array}$ \\
\hline 3 & $\begin{array}{l}\text { Lack of control of keeping of the } \\
\text { heating system security zone }\end{array}$ & $\begin{array}{l}\text { Impossibility of carrying } \\
\text { out full diagnostics }\end{array}$ & $\begin{array}{l}\text { Local, leads to } \\
\text { incorrectness of the } \\
\text { estimates }\end{array}$ \\
\hline 4 & $\begin{array}{l}\text { Existence of water in the camera of } \\
\text { the heating system (owing to } \\
\text { various factors) }\end{array}$ & $\begin{array}{l}\text { Corrosion in case of } \\
\text { preservation of water in the } \\
\text { camera }\end{array}$ & $\begin{array}{l}\text { Local, external } \\
\text { corrosion }\end{array}$ \\
\hline 5 & $\begin{array}{l}\text { Lack of ventilation in the chanell- } \\
\text { laid systems and cameras }\end{array}$ & $\begin{array}{l}\text { Corrosion in case of such } \\
\text { situation }\end{array}$ & $\begin{array}{l}\text { Local, external } \\
\text { corrosion }\end{array}$ \\
\hline 6 & $\begin{array}{l}\text { Existence of garbage in the camera } \\
\text { of the heating system }\end{array}$ & $\begin{array}{l}\text { Damages of the structures } \\
\text { in case of such situation }\end{array}$ & $\begin{array}{l}\text { Local, different } \\
\text { damages }\end{array}$ \\
\hline 7 & $\begin{array}{l}\text { Violation of the technological } \\
\text { modes in heat exchangers, } \\
\text { malfunction in them }\end{array}$ & $\begin{array}{l}\text { Exception of hit of oxygen } \\
\text { along with tap water }\end{array}$ & $\begin{array}{l}\text { Local, internal } \\
\text { corrosion }\end{array}$ \\
\hline
\end{tabular}

Considering the matter of reliability more systemically, it is possible to note that monitoring of technical condition and maintenance costs for each site of the heating systems throughout all the cycle of maintenance (normative and in case of extension of the resource) has to become the information basis of the risk management system of HSO at the maintenance stage. Its absence in HSO enhances the risks of not provision with heat of the required quality and volume at the scheduled time. The analysis of the data obtained within monitoring allow the risk management system of TSO to predict the reliability of each site of the heating system in the form of a calculated numerical indicator.

The aforesaid features, leading to the decrease in reliability determine the need to carry out diagnostics of the heating systems condition, directed to the risk prevention. The research proved, that drawing up plans of diagnostics, the choice of diagnostic tools, assessment of the obtained data and formation of the conclusion on the reliability of the heating systems is the difficult issue, first of all because the majority of these engineering structures is laid underground. Respectively, their diagnostics is expensive and it is not always possible to have a warranty of 100 percent reliability of the received results. Primary information on the actual state of the engineering structures, which allow to range 
the heating systems under maintenance according the degree of compliance of their states to the requirements of reliable heat supply for consumers has to become the result of diagnostics. Indirect data on the heating systems reliability can be obtained in the risk management system of TSO on the following basis:

- data on the refusals (incidents), which took place earlier; the recorded places of flooding, slushing, failures or motions of soil;

- data on malfunctions of the basic-and-compensation system and the protection structures of the channel;

- the abnormal thermal zones, found according to the results of thermo-vision aerial photograph, revealed when carrying out acoustic tomography and/or non-contact magnetic diagnostics or found by any other integrated method of diagnostics.

Depending on the degree of completeness of the works on technical diagnostics, which was performed earlier, executive and operational technical documentation, results of the regular surveys, data of monitoring by the destroying methods (the analysis of damages at tests of pipelines on positive pressure and elevated temperature; bench tests on durability; research of chemical composition etc) and also results of monitoring by non-destructive methods are subject to the complex analysis.

The total characteristic of the engineering structures reliability, connected with the considered three stages of the life cycle of the heating systems, presented in the form of distribution of the frequency of emergence of separate types of damages, defects and related failures of the engineering structures is presented in Table 5.

Table 5. Reasons of the decrease in reliability

\begin{tabular}{|l|c|}
\hline \multicolumn{1}{|c|}{ Reasons of the decrease in reliability } & $\begin{array}{c}\text { Share of damages in the } \\
\text { total quantity, } \%\end{array}$ \\
\hline 1. External corrosion and electrocorrosion & 55 \\
\hline 2. Internal corrosion & 35 \\
\hline 3. Not-corrosion damages & 10 \\
\hline
\end{tabular}

The data presented in Table 5 reflect the qualitative interrelation of the reasons of the decrease in the heating system reliability as well as technical, technological and labour risks, considered in the particular classification of risks "Matrix of seven" and allows to pass to the more detailed analysis of substantial characteristic of each of risks within the HSO risk management system organization.

\section{Discussion}

One of the most debatable and at the same time significant issues of the modern risk management, especially in relation to assurance reliability of the heating systems maintenance, is correlation of risks and reliability. The authors offer to discuss two methodologic-and-methodical issues:

1) definition of parameters/indexes of risk assessment, identification and management of which within the risk management system of TSO allows to provide the corresponding reliability productively, efficiently and in due time;

2) development of models for assessment and prediction of reliability, which are based on accounting of the risk-characterizing factors.

Considering the results of the previous research by the authors $[5,6]$ and also the reasonings given above, it is offered to use two parameters for the assessment of the specified risks:

- the probability of an event and/or the realization of action, interfaced to the emergence of the reasons of the decrease in reliability; 
- the deviation from the planned/expected reliability level of the heating systems maintenance.

The need of high-quality and quantitative measurement of these parameters within the assessment of operational risks predetermines the establishment of some indicators of assessment. It is offered to use:

- the assessment of probability $(\mathrm{P})$ which does not demand any additional explanations;

- the assessment of the deviation from the planned level of quality of the services provided by $\mathrm{HSO}(-\Delta \mathrm{Q})$.

The index of quality is chosen, taking into account its integrated essence, complexity of assessment and significance of the achievement of the planned value of quality of the services, provided by TSO. The methodology of the modern risk management provides consideration of all the range of the deviation both negative and positive, but owing to the specifics of the considered risks and semantic filling of the assessment index of reliability level of the heating system maintenance (quality of the rendered services), at the quantitative assessment of risks only the negative deviation is considered.

It is necessary to pay attention, that on the specified indexes the set of particular risks $\mathrm{rnm}$, revealed on the basis of application of the classification "matrix of seven" for the risks of the heating systems maintenance (Table 1) are estimated. The template fragment for the assessment of risks of the heating system maintenance and the example are presented in the Table 6.

Table 6. Template for the quantitative assessment of risks of the heating systems maintenance

\begin{tabular}{|c|c|c|c|c|}
\hline \multirow[b]{2}{*}{$\begin{array}{l}\text { Group of } \\
\text { risks }\end{array}$} & \multirow[b]{2}{*}{$\begin{array}{l}\text { Code and name of } \\
\text { particular risk }\end{array}$} & \multicolumn{2}{|c|}{ Value of the assessment indexes } & \multirow[b]{2}{*}{ Note } \\
\hline & & $\begin{array}{c}\text { probability of } \\
\text { an event and/or } \\
\text { realization of } \\
\text { action, } P \\
\end{array}$ & $\begin{array}{c}\text { deviation from } \\
\text { the planned } \\
\text { level of quality, } \\
-\Delta Q \\
\end{array}$ & \\
\hline $\begin{array}{l}\text { Constructive } \\
\text { risks }\end{array}$ & $\begin{array}{l}\mathrm{r}_{11} \text { is the constructive risk, } \\
\text { influencing the delivery time } \\
\text { of service } \\
\mathrm{r}_{12} \text { is the constructive risk, } \\
\text { influencing service volume }\end{array}$ & 0.04 & $13 \%$ & \\
\hline $\begin{array}{c}\text { Technological } \\
\text { risks }\end{array}$ & $\begin{array}{l}\mathrm{r} 21 \text { is the technological risk } \\
\text { influencing time of service } \\
\text { delivery }\end{array}$ & 0.3 & $5 \%$ & \\
\hline$\ldots$ & $\ldots$ & $\ldots$ & $\ldots$ & $\ldots$ \\
\hline
\end{tabular}

The results of the research, received and described above as well as carrying out the correlative-and-regression analysis allowed the authors to offer the following models of assessment and prediction of reliability and also the choice of the optimal variant of the management decision, regarding assurance reliability of the heating systems maintenance.

1. Model of the assessment of the current reliability level, depending on current state of the heating system:

- general view of model:

where

$$
R h s=d_{1} p_{1}+d_{2} p_{2}+d_{3} p_{3}
$$

$d_{i}-$ the setpoint values, reflecting the share of influence of each parament of the heating system on the current level of its reliability:

$\mathrm{d}_{1}=0.55 ; \mathrm{d}_{2}=0.35 ; \mathrm{d}_{3}=0.10$

$\mathrm{p}_{1}$ - current state (level) of external corrosion and electro-corrosion on the i-th heating system;

$\mathrm{p}_{2}$ - current state (level) of the internal corrosion on the i-th heating system;

$\mathrm{p}_{3}$ - current state (level) of not-corrosion damages on the i-th heating system; 
- model for the i-th heating system:

where

$$
\text { - } R h s_{i}=0.55 p 1_{i}+0.35 p 2_{i}+0.10 p 3_{i}
$$

$R h s_{i}$ - current reliability level of the $i$-th heating system;

$p 1_{i}-$ current reliability (level) of external corrosion and electro-corrosion of the $i$-th heating system;

$p 2_{i}$ - current reliability (level) of internal corrosion of the $i$-th heating system;

$p 3 i$ - current reliability (level) of not-corrosion damages of the $i$-th heating system.

2. Model of the predicted level (Rhs) of reliability, depending on the expected / possible condition of the heating systems in the perspective period:

- general view of model:

where

$$
R h s=K+k_{1} p_{1}{ }^{t}+k_{2} p_{2}{ }^{t}+k_{3} p_{3}{ }^{t},
$$

$\mathrm{K}$ - value of the influence of the parametrs of the state of the heating systems, not taken into account in the model;

$\mathrm{k}_{\mathrm{i}}$ - the constants reflecting the extent of influence of the $\mathrm{j}$-th parametr of the state of the heating system on the level of its reliability. In the considered situation $\mathrm{j}=3$.

According to the the carried-out analysis the following values of coefficients were set as: $K=0.879 ; \quad k_{1}=-7.21 ; \quad k_{2}=-5.59 ; k_{3}=-0 ., 18$. Negative value $k_{i}$ reflects the negative influence of the revealed parameters on the reliability level, i.e. the more corrosion level, the lower reliability level. moment;

$p_{1}{ }^{t}-$ level of external corrosion and electro-corrosion of the heating system in t-th

$p_{2}{ }^{t}$ - current level of internal corrosion of the heating system in t-th moment;

$p_{3}{ }^{t}$ - current state level of not-corrosion damages of the heating system in the t-th moment.

where

$\checkmark$ Model for the $i$-th heating system

$$
H t_{i}=0.879-7.21 p 1_{i}{ }^{t}-5.59 p 2_{i}{ }^{t}-0.18 p 3_{i}{ }^{t},
$$

$H t_{i}$ - the reliability of the $i$-th heating system maintenance in the $t$-th moment;

$p 1_{i}{ }^{t}$ - expected / possible level of external corrosion and electro-corrosion in the ith of the heating system in the $\mathrm{t}$-th moment;

$p 2_{i}{ }^{t}$ - the expected / possible level of the internal corrosion on the i-th of the heating system in the $\mathrm{t}$-th moment;

$p 3_{i}{ }^{t}$ - expected / possible level of not-corrosion damages on the i-th heating sytem in the $\mathrm{t}$-th moment

3. The model of the choice of an optimal variant of the managerial decision, on the assurance of reliability of the heating systems under maintenance. For the development of this model (in general) we will define the criterion of optimization and target function and also the system of expedient restrictions.

Considering technical-and-economic specifics of the purpose and the results of the research, which are carried out and descibed above, there are two options of the formation the target function: with the use of one or three and all the (three) criteria at the same time. It is expedient to use time/term (T), volume (V) and quality $(\mathrm{Q})$ of the services provided by theheating systems as similar criteria.

More detailed comprehension of the features of the specified parameters allows to suggest that the uses of the criterion of quality of the rendered services and the use of onecriteria optimizing model is more competent as in essence, and taking into account the requirement not of complication of the use of the offered methodical tools of assuring reliability of the heating systems under maintenance on the basis of the risk management of HSO. 
Therefore, in general the optimizing model can be presented as follows:

- $\quad$ target function $Q \rightarrow \max$

- system of restrictions:

$$
\left\{\begin{array}{l}
T s_{\text {min }} \leq T \leq T s_{\text {max }} \\
V d_{\text {min }} \leq V \leq V d_{\text {max }} \\
P g_{\text {min }} \leq P g \leq P g_{\text {max }} \\
r_{n m_{\text {min }}} \leq r_{n m} \leq r_{n m_{\text {max }}}
\end{array}\right.
$$

The following designations in the system of restrictions are used in the presented model:

$T s_{\min }$ and $T s_{\max }$ - the minimum and maximum terms / time, set respectively of rendering services of $\mathrm{HSO}$;

$V d_{\min }$ and $V d_{\max }$ - demanded respectively lower (minimum) and top (maximal) volumes of rendering of services of $\mathrm{HSO}$;

$P g_{\min }$ and $P g_{\text {max }}$ - minimum and maximum values of the g-th type of resources, which is demanded/used for rendering services by the heating systems. According to earlier conducted research, carried by the authors $[1,8,9]$ it is necessary to consider production, information, logistic, financial, human and innovative resources.

$r_{n m \min }$ and $r_{n \max }$ - minimum and maximum values of the particular risks of the $\mathrm{m}$ th type of the component (component of heat supply processes) and of the n-th type of parameters (parameter of service of heat delivery) according to the matrix of particular classification of risks ("Matrix of seven"), presented in Table 1. The range between min and max values for each type of risks, for each group or for the risk in general is necessary to be considered as a corridor of acceptable risk.

It should be noted that in relation to the first two models the professional discussion, concerning their effectiveness of application within the assurance of the reliability of the heating systems maintenance is possible. The third optimizing model demands professional discussion regarding the further specification of the parameters, entering the model and, in particular, the applied restrictions, expediency of the use of onefactorial or multiple-factor optimization and also the choice of a method of acceptance of an optimal solution and the verification of the offered model.

There is an issue of the structure of this system and the specification of its components.

Traditionally any management system consists of two subsystems: managing and managed. Contents and the structure of the managed subsystem, predetermined by structure of the management object consists of:

1) systems of risks of the heating system maintenance $[10,11]$ :

- in case of wide consideration the system of risks as the object of management includes two classes of risks: the types of risks, connected from functioning of HSO in general. As for assessment and risk management the particular risks are used, the maximum quantitative set of types of risks makes 52 of them. In addition it is necessary to include 12 more particular risks of the heating systems maintenance, united into the 7th groups of types of risks (see Table 1).

- in case of narrow consideration of quantity and structure of the managed subsystem of the risk management system of HSO one should consider only risks of the heating systems maintenance, i.e. 12 particular risks.

2) the indicators of the assessment and factors, affecting the reliability level and used in the models of prediction, assessment of the reliability level and making an optimal decision [12]. 
The operating subsystem determines the subjects of management and set of managerial tools. In relation to the heating systems it is expedient to recommend the two-level model, including strategic and tactical levels of risk management. At the same time managerial decisions and influences of the operational level join, "tightened" to the tactical level. In Table 7 the recommended services/divisions, acting as subjects of management of operational risks, are specified with the distribution of basic tasks of risk management [13, 14].

Table 7. Recommended services/divisions acting as the subjects of the operational risks management

\begin{tabular}{|c|c|c|}
\hline $\begin{array}{c}\text { Level of } \\
\text { management in } \\
\text { the operating } \\
\text { subsystem }\end{array}$ & $\begin{array}{c}\text { Possible names of the } \\
\text { structural divisions of } \\
\text { the risk management at } \\
\text { the heating systems }\end{array}$ & $\begin{array}{c}\text { The carried out tasks of the operational } \\
\text { risks management }\end{array}$ \\
\hline Strategic level & $\begin{array}{l}\text { Board / directorate / } \\
\text { board of directors }\end{array}$ & $\begin{array}{l}\text { 1. Acceptance of the strategy and methodology } \\
\text { of the operational risks management } \\
\text { 2. Establishment of the acceptable levels of } \\
\text { risk (corridor of risks) } \\
\text { 3. Acceptance and approval of the executive } \\
\text { procedures of the risk management } \\
\text { 4. Motivation to effective and productive } \\
\text { operational risks management }\end{array}$ \\
\hline Tactical level & $\begin{array}{l}\text { Specialized service on the } \\
\text { risk management: } \\
\text { department } \\
\text { administration/ } \\
\text { department of risk } \\
\text { management }\end{array}$ & $\begin{array}{l}\text { 1. Description of threats, identification and } \\
\text { monitoring of risks } \\
\text { 2. Classification, assessment and analysis of } \\
\text { operational risks } \\
\text { 3. Reasonable choice and realization of } \\
\text { methods of risks management } \\
\text { 4. Monitoring and correction of the results of } \\
\text { the managerial impact on the risks } \\
\text { 5. Acquisition and formation of the database of } \\
\text { the risk management }\end{array}$ \\
\hline
\end{tabular}

The tools of the modern risk management, which use is expedient within the impact on the maintenance risks, carried out by the specialized services risk management, are presented in others works by the authors systemically and explicitly $[5,6,15,16]$.

\section{Conclusions}

Nowadays some consequences of laying of heating systems of "the socialist period" of our history, which characterized with low quality of design, construction and also the low level of the organization of the engineering structures maintenance emerge in the countries of the former Soviet Union, including the Russian Federation and Uzbekistan. That led to the decrease in the heating systems reliability eventually and raised the issues of reorganization of management for overcoming the old approaches to the organization of maintenance as well as for the development of modern methods of management. Both motivation to the HSO transformations and the state policy in the heat supplying industry, which is being carried out by the government act as important factors of realization of such a transition. The laws, governing the relations of the participants of heat supply make up the basis for the heat supplying activity in both countries. At the same time new mechanisms of the industry financing, which provide qualitatively different opportunities for the improvement of management in $\mathrm{HSO}$, have entered the processes of reorganization of the industry in both countries recently.

In these conditions the minimization of risks, connected with violation of terms, volume and quality of the heat energy, delivered to consumers, has to be the main reference point 
for the reorganization of management in HSO. It is offered to carry out the risk management systemically, assuring the reliability of the heating systems maintenance on the basis of the creation of the risk management system of the heat-supplying organizations. In this regard the main aspects of the creation of such systems were considered, taking into account the assessment of the available information support of the maintenance, which has to provide the possibility of full-fledged assessment of the reliability, differentiating the related risks of HSO during the stages of lifecycle of the engineering structure. The analysis proved, that modern HSO are not able to provide all the required information for forecasting and localization of risks. Nowadays only primary information, which is generated in each HSO in its own way, is available.

However, the offered elements of the risk management system in HSO, which include the classification of risks, taking into account the specifics of activity of these organizations on the basis of the equilibrium-and-balanced approach, the model of assessment and forecasting of the reliability, taking into account the factors, characterizing risks, demand more system and purposeful work on the organization of information on the reliability and risks of the heating systems maintenance. In this regard the authors offered some actions of organizational character for the creation of the risk management system in HSO, which stage-by-stage realization will stimulate HSO to transformations in the sphere of the information support, making it adequate to the modern tools of risk management.

\section{References}

1. A. Damodaran, Strategic risk management. Principles and techniques (Moscow, Williams publishing house, 2018)

2. The integrated risk management [Digital resource] Access Mode: http://www.gaap.ru/biblio/corpfin/finman/077.asp

3. Risk management maturity level assessment in Russia [Digital resource] Access Mode: https://www2.deloitte.com/ru/ru/pages/risk/articles/maturity-level-of-riskmanagement.html

4. Committee of the organizations sponsors of the Commission of Tredvey "COSO.org" [Digital resource] Access Mode: https://www.coso.org.

5. N. Verstina, MATEC Web of Conferences, 106, 08091 (2017)

6. N. Verstina, E. Evseev, MATEC Web of Conferences, 106, 08090 (2017)

7. R. Kachalov, Management of economic risk: theoretical bases and appendices (Moscow, Saint-Petersburg, Nestor History, 2012)

8. O. Korniyenko, V. Makarova, Relevant issues of the evaluation of the corporate risk management efficiency (Saint-Petersburg, Polytechnic University publishing house, 2015)

9. V. Kunin, Risk management of an industrial entrepreneurship (theory, methodology, practice) (Saint-Petersburg, Publishing house of the Saint-Petersburg academy of management and economy, 2011)

10. Harchenko S. G., Dorokhina E. Yu. The organization of risk management at the construction enterprise. - M.: Gostekhizdat, 2015. - 1963 with.

11. K.H. Spencer Pickett, Enterprise Risk Management: A Manager's Journey (Hoboken, John Wiley \& Sons, Inc., 2006)

12. Committee of Sponsoring Organizations of the Treadway Commission, Enterprise Risk Management - Integrated Framework (New Jersey, COSO, Jersey City, 2004)

13. E. Capri, D. Karpouzas, Pesticide Risk Assessment in Rice Paddies: Theory and Practice (UK, Oxford, Linacre House, 2008) 
14. Th.L. Barton, W.G. Shenkir, P.L.Walker. Making Enterprise Risk Management Pay Off: How Leading Companies Implement Risk Management (New Jersey, Upper Saddle River, Financial Times/Prentice Hall PTR Pearson Education, Inc., 2002)

15. N. Verstina, E. Evseev, MATEC Web of Conferences, 193, 05007 (2018)

16. N. Verstina, E. Evseev, MATEC Web of Conferences, 251, 05026 (2018) 